\title{
Tax behaviour relating to the review of a revised regional tax policy: a study in Greece
}

\author{
Nikolaos Varotsis ${ }^{1 *}$ (10) and loannis Katerelos ${ }^{2}$
}

\author{
*Correspondence: \\ nvarotsis@ionio.gr \\ ${ }^{1}$ Tourism Department, Ionian \\ University, Building "Calypso", \\ P. Vraila Armeni 4, 491 \\ 00 Corfu, Greece \\ Full list of author information \\ is available at the end of the \\ article
}

\begin{abstract}
The failure over time of the tax system in Greece to harmonize with a sound and efficient fiscal mix raises questions about the possibility of a radical restructuring. The last decade of continuous tax reforms has neither particularly restricted the black economy nor provided the government with fresh fiscal resources, and it has outgrown its arrears. A socially acceptable fiscal policy may lead to a new, sound fiscal policy mix. Tax restructuring that strengthens the tax base at the regional, local or European levelcompared to its structuring at the one-sided governmental level to date-may be a key factor in the social acceptance of a new tax system. The degree of tax decentralization of the applied tax policy is likely to improve fiscal order and management on the one hand and, on the other hand, enhance tax revenues by enhancing tax compliance.
\end{abstract}

Keywords: Regional tax, Public finance, Fiscal policy, Tax restructuring, Tax behaviour

\section{Introduction}

A significant proportion of Greek society has created a firm belief (Gainous et al. 2010) that tax laws are unfair and do not apply to everyone equally. This view largely stems from the inability of the public to discern, at the right time, those who attribute legitimate taxes (Robbins and Kiser 2018) versus those who evade taxes (Slemrod 2007).

The main failure of the tax system in Greece is that it reproduces "tax evasion" and overdue debts of established taxes, distorting the real economy. Even continuous tax "reforms" have not stopped the continuous reproduction of tax evasion or the continuous increase of non-taxable income.

The failure of the tax system is broadening as new financial accounts are recorded. The continuous growth of overdue debts highlights the failures of the tax system, although, in the last 4 years, these failures have been compounded by the constant changes in the legislative framework. The total collectability (timed payments) of income taxes, valueadded tax, other indirect taxes, the real estate single tax and other real estate taxes amounted to $80.67 \%$ at the end of 2017 . However, the total overdue debts at the end of 2018 exceed $€ 104.0$ billion (AADE 2019), a value that more than tripled during a decade of continuous tax reform while the total number of debtors surpassed four million.

(c) The Author(s) 2020. This article is licensed under a Creative Commons Attribution 4.0 International License, which permits use, sharing, adaptation, distribution and reproduction in any medium or format, as long as you give appropriate credit to the original author(s) and the source, provide a link to the Creative Commons licence, and indicate if changes were made. The images or other third party material in this article are included in the article's Creative Commons licence, unless indicated otherwise in a credit line to the material. If material is not included in the article's Creative Commons licence and your intended use is not permitted by statutory regulation or exceeds the permitted use, you will need to obtain permission directly from the copyright holder. To view a copy of this licence, visit http://creativeco mmons.org/licenses/by/4.0/. 
The last decade of continuous tax reform at the same level of government, which aims for monotonous collection measures to meet the annual budgetary targets, has clearly led to a fiscal fatigue of the tax base. In other words, taxable persons who are subject to taxes gradually (Young 1990) become less able to make their payment. Changes in the tax system do not increase the tax base, but instead appear to saturate the existing base. The continued production of overdue debts challenges the effectiveness of the existing tax system, as well as lasting legislative changes, exacerbating fiscal apnea. Financial resources are exhausted by perpetuating a climate of uncertainty in the growth prospects of the real economy.

Economic cachexia is fuelled by rising taxes that do not achieve tax inequality by moving indirect income from categories of taxpayers who cannot conceal income (employees, pensioners, etc.) to other categories of taxpayers who persist in their delinquent behaviour while maintaining tax evasion at high levels approaching a quarter of GDP. In addition, economic apnea is maintained by the high indirect taxation that affects the inertia of economic activity (Katsimi and Moutos 2010), given that, in Greece, the valueadded tax rate is the third highest among OECD countries, while it is widened by very high insurance contributions. The claim that high indirect taxation restrains economic model failures that aggravate current account performance coupled with high insurance contributions is contrasted by macroeconomic performance that does not create the appropriate growth conditions to improve the real economy.

It is possible that the long-term presence of a large percentage of shadow economies in Greece-which could not restrict multiple tax reforms-is not limited to the solvency of fiscal policy but extends to the tax evasion tolerance of the whole tax base. The constant continued presence of the shadow economy in Greece does not exclude a social basis for the tax base, which has deteriorated to withstand tax evasion and survivors with high non-taxable income by adopting unpredictable tax behaviour. In this case, taxpayers' tolerance of the shadow economy cannot be limited either by temporary intensities of tax control or by horizontal changes in the tax system. This illegal tax behaviour may include social and psychological characteristics related to the reduction of fiscal and tax policy, the management of fiscal resources and the levels of tax decentralization that contribute to maintaining the same attitude.

\subsection{Applicable tax policy mix}

Over the last 10 years, a new model of tax policy has been formulated with a series of regulations. Since 2019, there have been significant changes in the implementation of tax legislation with a series of legislative provisions and more than a hundred tax law codification conversions, followed by a number of circular interpretative directives which have completely revised the applicable tax policy (Naftemporiki 2017). The legislative reform of the tax model includes the Greek new income tax code (Greek Tax Code 2013a), the new tax procedure code (Greek Tax Code 2013b), the new real estate single tax and the implementation of the Greek accounting standards (Greek Tax Code 2014). The main axes of the new tax reform are presented in Fig. 1.

The main objectives of the new tax reform are to simplify the monitoring of financial transactions, the submission of taxpayers' declarations, the diversification of the imposition of penalties and the change in the control procedures and the enforcement of 


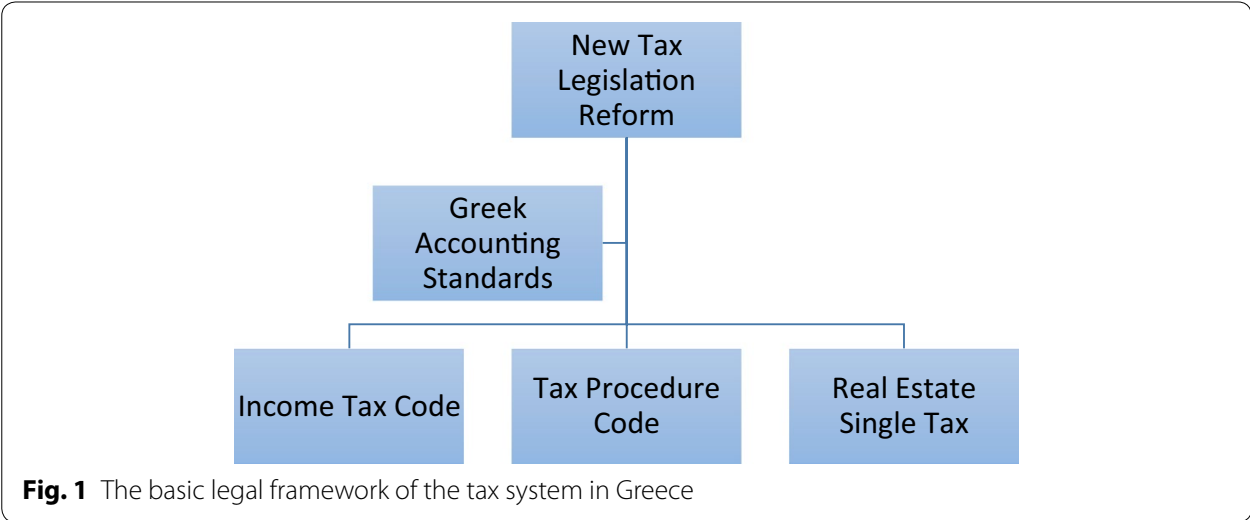

compulsory recovery measures. The new income tax code focuses, in conjunction with the legal framework for the prevention and suppression of money laundering (Greek Tax Code 2008), on identifying and taxing undeclared income and, in particular, income derived from illegal activities that cannot be legally justified (money laundering) or from unidentified sources of income. At the same time, it applies the mandatory application of market and real estate preservation documents. The new tax procedure code including sanctions differentiates between taxpayers while allowing for earlier tax cases to be reconciled to a lower level. Additionally, with the changes in the audit process, the tax authority is better able to interconnect through an electronic system of bank accounts and the implement a shorter process of automated seizure of bank accounts for taxpayers in public debts (O’Neill et al. 2005). With the single property tax, a uniform property tax is imposed on almost all owners, while capital gains, large immovable property and real estate transfer taxes are retained. Changes have also been made to indirect taxation by enforcing value-added tax (VAT) rates and imposing a series of additional indirect taxes (fuel, food service, telephony, etc.).

The tax policy applied over the past 5 years moves on three main axes: to review the (increase) in the taxation of income or property acquired, the determination of income not only from its sources but also from living costs and the additional burden of indirect taxation. The electronic archiving of all taxpayers' transactions has been previously established, but was not practically implemented until now. Whilst apparently the tax mix applied tightens the taxpayer (Alogoskoufis 2019), it does not consider a number of important features of a tax population dominated by high fatigue and aversion to the taxing authority due to the financial failures and injustices that have been caused by it to date.

It is clear that central (government) planning and management is maintained for all tax revenues without providing for an autonomous tax governance at the regional and/or local levels (Porter 1996). This approach does not integrate the culture and social characteristics of the population to shape the new tax policy (Nantell 1999), instead insisting on the implementation of potentially successful prescriptions of other tax systems. Fiscal management remains independent of the formulation of the tax policy followed (McMillan and Woodruff 2002). Social consensus remains unknown with regard to implementing the new reforms that bring the new tax framework. Care has not been taken to remedy the injustices the tax system has brought to the population to date (according to 
AADE annual statistics in $2018,90 \%$ of the income taxes are paid by $19 \%$ of the population), but only blind horizontal expansions of the tax base have been pursued. Moreover, no timetable has been provided for the modernization of all state bureaucratic procedures linked to an efficient economy in which the new tax framework will be applied. It is still unknown whether the information systems can perform all the cross-checks required to capture the financial transactions according to the total taxes paid and not simply to control their realization. However, the tax base has theoretically increased since the new tax reform provides for more taxes without having calculated the operating cost of the tax base elasticities (Bruce et al. 2006) or adjusting to the new tax base.

\subsection{Local government finances}

There are three main sources of local government revenue: income from taxation, grants and loans (Easterly and Rebelo 1993). For the execution of works and the provision of services, municipalities impose taxes, fees, royalties and levies on their citizens, provided that they do not have the same tax authority but always act within the framework of a law which identifies the persons liable, the subject of taxation, rates and exemptions. In this case, the receipt and collection of income is done by the municipalities themselves, as opposed to the central resources collected from the state and attributed to the Local Authorities. A disadvantage of local taxation is the creation of horizontal and vertical fiscal disparities and inequalities in the provision of public services and taxation of citizens.

The introduction of municipal taxes, fees, royalties and levies (Heymans 2006) is done by a formal law, which either imposes them automatically in favour of the first-degree municipalities (without the decision of the Municipal Council) or provides the possibility to the Local Authorities to impose them by a decision of the City Council. In the latter case, enforcement is at the discretion of the City Council (Braithwaite et al. 1987). The fees are always imposed by a decision of the Municipal Council, which determines their rate.

There is still a difference in the two levels of government-central and local-in terms of the consequences of tax evasion or the income elasticity of a tax, especially if the local government imposes only a small or a single tax. A substantial difference is observed in the economic operation of the two levels of administration. The central government functions more as a means of ensuring economic stability and redistribution of income in relation to the local government (Weingast 1995), and they do not have a correspondingly important role. Thus, a tax may seem more appropriate in terms of effectiveness and fiscal justice when applied centrally than at local level.

\subsection{Tax decentralization}

Tax decentralization is the extent to which the central government transfers a tax burden to a local authority (Davulis et al. 2013) and is valued based on the percentage of local government tax revenues in the total public tax revenues, or by comparing local government revenue with that of the local government's central administration. In this case, the question arises as to the distinction between tax revenues belonging to the taxcollecting step and those belonging to that level, in favour of which they are charged by another level of administration. 
A significantly higher degree of decentralization is found in the Nordic countries (Tøssebro et al. 2012), and particularly in Denmark (Iversen 1996), where local government revenue reaches $81.46 \%$ of central government revenue. As shown in Fig. 2 below, the structure of fiscal decentralization varies across 15 countries in Europe (Council of Europe 2000):

Figure 3 below shows the situation in the European states as regards the percentage structure of local government revenues. As shown in Fig. 3, Greece, the Netherlands and Portugal secure the bulk of their revenue from non-tax revenues such as subsidies and borrowing.

In the European Union, the composition of budgetary resources has not changed over time. As seen from Fig. 4 there is a slight increase in government intervention in central level (European Commission 2017).

\subsection{Tax behaviour}

Individual tax behaviour (Katerelos and Varotsis 2017) often deviates from the rational model (Conlisk 1996) to reward personal well-being. Individual behaviour and decision-making (Edwards 1954) differ from rational selection by enhancing personal heuristics with cognitive constraints (Tversky and Kahneman 1974). The sovereign characteristics of the taxpayer are to adopt rational self-esteem for personal

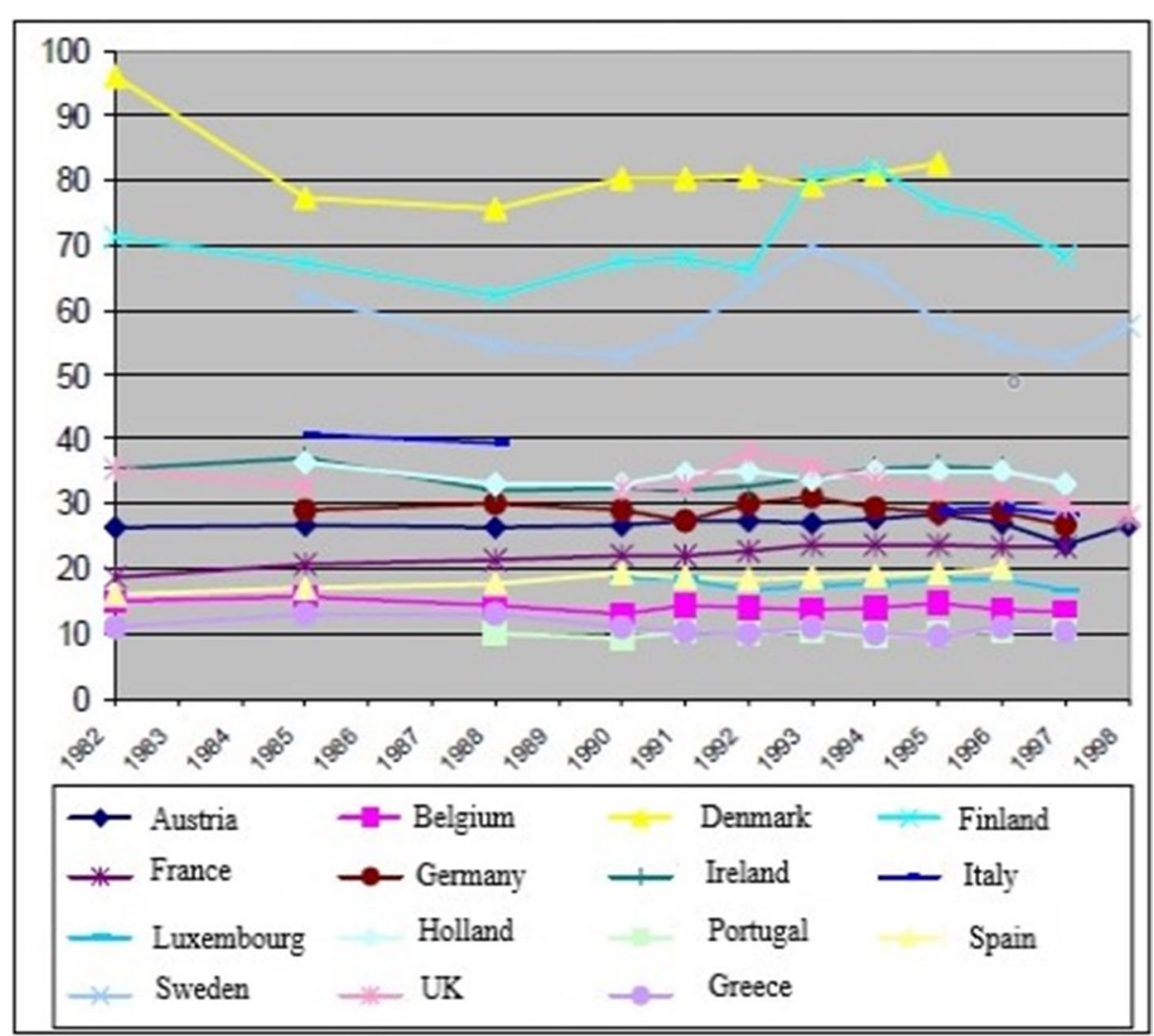

Fig. 2 Percentage of local government revenue in central government revenue Source: European Commission (2017) 


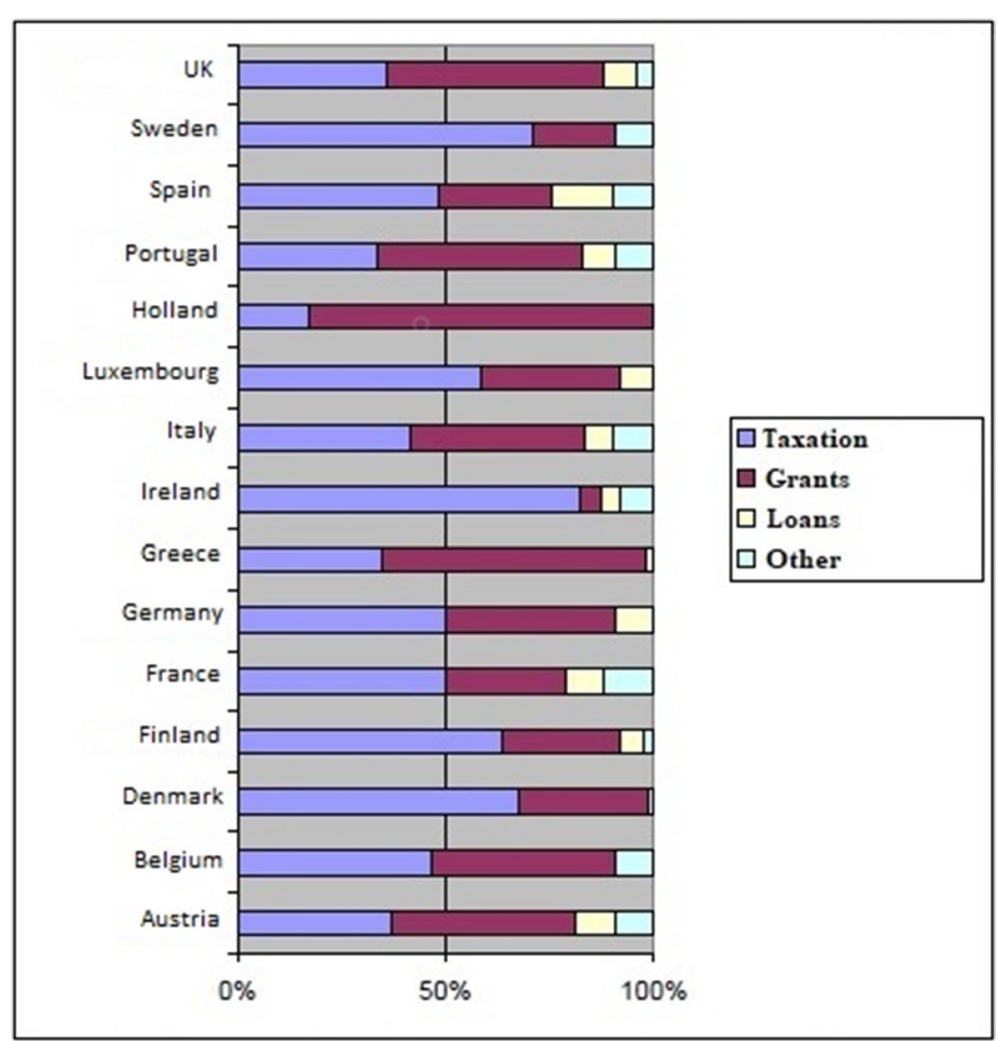

Fig. 3 Synthesis of local government revenue Source: European Commission (2017)

material satisfaction. Tax evasion occurred alongside taxes (Kirchler et al. 2008) influenced by perceived justice in the tax system (Andreoni et al. 1998). Compliance with tax rules is a priority for public finances and affects equality, efficiency and ultimately the impact of a tax system. When a significant proportion of the population can avoid or fail to systematically pay or not pay the corresponding taxes, the tax system becomes unfair, punishing honest taxpayers by imposing additional necessary taxes.

On the other hand, the tax distorts the effectiveness of the tax system (Kaplow 1996), impacting the welfare of taxpayers (Cullis and Lewis 1997). The imposition of increased tax rates and the ingenuity of taxing is too simple to achieve economic growth in a socio-economic system (Murphy 2008), and may lead to a temporary increase in tax revenues using tax models with low social efficiency (Wenzel 2004). Maintaining a "marginal" behaviour among the population with mixed strategies to temporarily respond to taxes implies adjusting to a pattern of avoidance of taxes (Méder et al. 2012). In addition, a taxation system of over-filing is fully exploited, with unspecified effects on the real economy. Excessive taxation not only leads to the tax exhaustion of the population but also sparks social reactions for a so-called ineffective government. A tax system acceptable to the taxpayer is a prerequisite for an effective tax policy (Laffer 2004). 


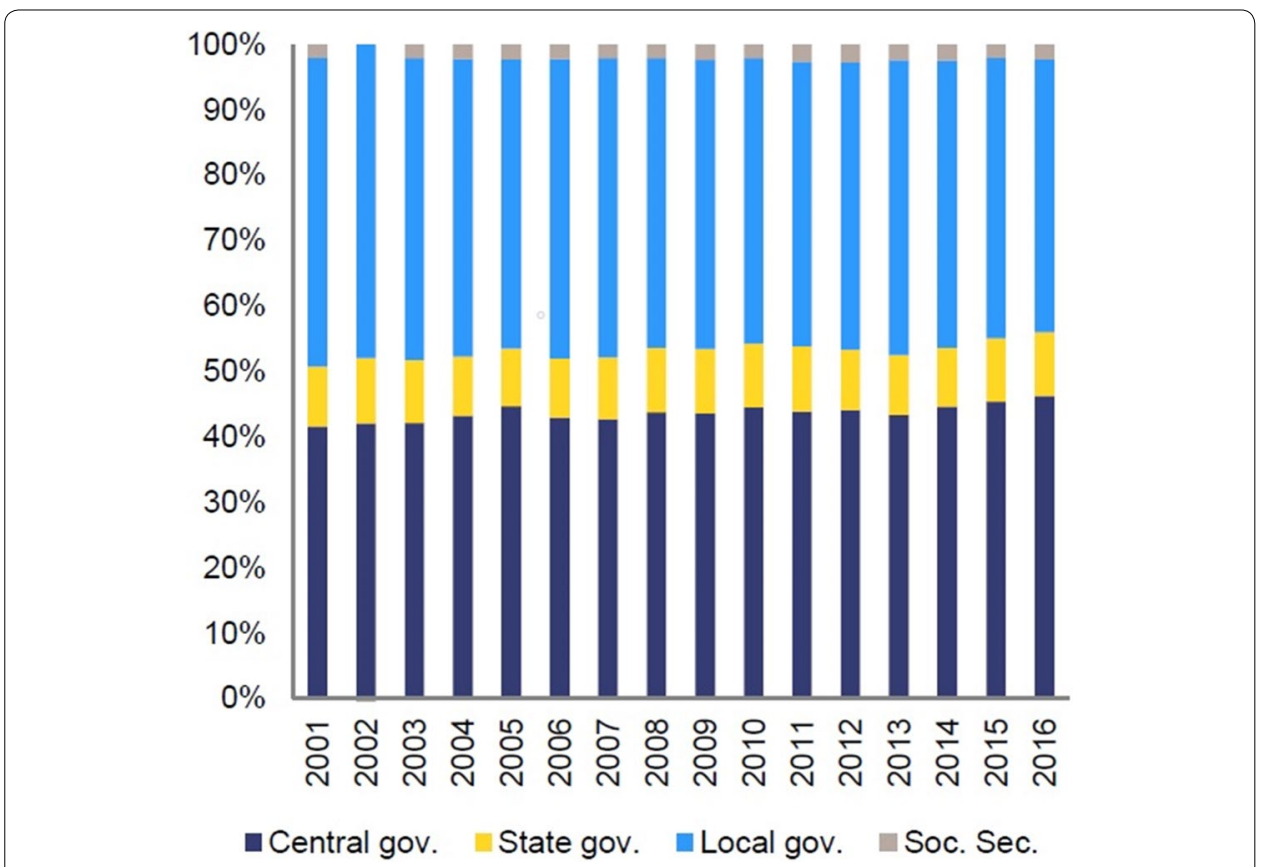

Fig. 4 Revenue distribution structure at central, state and local level Source: European Commission (2017)

\subsection{Social consensus}

Social consensus is an agreement about the need for a commonly accepted social goal (Wood 1989; Weller 2007) by all parties involved. Social consensus, also referred to as functionality, is based (Keltner and Kring 1998) on self-preservation and the social responsibility of societies (Sutinen and Kuperan 1999), which are balanced by social acceptance in order to maintain the existing social order.

Social consensus contradicts (Ross et al. 1977) conflict practice (Lane 1976), which requires a modification of the existing social establishment in order to make changes. Social consensus aims to balance society through a common agreement (Peredo and McLean 2006) on rules, values and operating rules in a specific context.

\subsection{Reform}

Tax reform is an indispensable component of state reform, a method (OECD 2010) chosen by an elected government for fiscal improvement with a view towards collecting taxes and the quality of public services. Reform is achieved by simplifying financial control, changing the progressivity of tax rates, imposing acceptable taxes, removing ineffective existing taxes, widening the tax base, and simplifying the collection of taxes (Slemrod 2001). State reform aims at simplifying citizens' transactions with the state, improving the quality of government services and the functioning of public services (Matei and LazĂR 2011) for the benefit of citizens (Allan and Scruggs 2004), improving the system (Perez and Westrup 2010) and improving the effectiveness of public works in terms of financial requirements and conditions.

The efficiency of the tax system and the efficiency of the state contribute to the efficient management of the available financial resources and bring about economic 
growth. It is a key factor of economic prosperity, social cohesion and the basic survival factor of an independent democratic state (Anderson 2001).

The effectiveness of the tax system depends on the economic environment, as well as on the social characteristics of taxpayers (Varotsis and Katerelos 2018). The sustainability of a tax system consists of a fair distribution of the tax burden relative to actual income (van Dijke and Verboon 2010). Pre-socialization of social justice by selfishness for taxation is the central factor for the effectiveness of a tax model (Fehr and Schmidt 1999). A fair distribution of tax burdens is a precursor to the taxpayer's compromise, with a consistent behaviour toward his tax obligations, while stressing the importance of a fair tax system (Barth et al. 2013).

\section{Methods}

\subsection{Description of the study area}

The subject of the investigation is Greek taxpayers. The quantitative survey was carried out on a sample of three hundred and twenty questionnaires that were distributed, completed and collected online. All the data collected constituted the sample for quantitative research. A small sample of 26 questionnaires was used during the pre-screening process, which was distributed to each participant personally, followed by the evaluation for the development of the final form of the questionnaire and the method of completing them.

\subsection{Rationale of the survey}

Investigating the redefinition of tax policy at the governmental, regional and European levels into a more socially acceptable fiscal policy mix is the main objective of the present research. The extent to which a tax reform can incorporate social acceptance is an original contribution of this research.

The research explores a new aspect of reforming the financial management system at three levels of management (regional, governmental, European), instead of a onesided approach at the governmental level, by examining the social consensus of such an effort. The survey was undertaken by drawing up and processing an anonymous questionnaire that was processed by a sample of the population who responded positively to an invitation to participate. The two limitations of the present study are the inability to verify the degree of honesty of anonymous questionnaires and the possible absence of a sample of a small number of elderly or part-time workers who did not respond to their invitations to participate in the survey.

\subsection{Sampling technique}

Recordings of views and attitudes were made upon the completion of the questionnaire. Data collection was conducted through the internet (Bryman 2012) using the online survey method (Reips 2002). This research was conducted using the questionnaire technique via the internet. The collection of data began in the first half of 2015 and was updated with enriched data from the second half of 2018. 


\subsection{Measures}

The overall sample of respondents consists of 320 anonymous questionnaires. A successful data report was performed (100\%). The participants consist of 159 men (49.7\%) and 161 (50.3\%) women. Participants of productive age (36-50) had the highest participation rate of $45 \%$, while the next largest participation rate was among young people, who represent $37 \%$ of the sample, and the remaining $18 \%$ was those older than 51 years. $13.4 \%$ are unemployed, $57.2 \%$ are employed in the private sector and $19.7 \%$ are employed in the public sector.

The declared income of the participants is divided into: $26.6 \%$ of those with an income of up to five thousand $€, 48.1 \%$ of those who claim income from six to twenty thousand $€, 21.9 \%$ of those who claim an income of twenty to fifty thousand $€$, and $3.4 \%$ of those reporting an income of more than fifty-one thousand $€$. Of these, $24.4 \%$ have up to 5 years of employment, 32.8\% from 6 to 15 years of employment, 36.3\% from 6 to 30 years of employment, while the remaining 7.5\% have more than 30 years of employment.

The level of education is characterized by $24.4 \%$ being secondary school graduates, $11.6 \%$ of those having attended a technical school, $44.1 \%$ of those having pursued tertiary education and $20.0 \%$ of researchers participating in postgraduate studies.

The individual and demographic characteristics of the sample are shown in Table 1.

\section{Results}

This questionnaire focused on the fiscal and fiscal policy mix. Participants were asked to propose a mix of tax and fiscal policy, as well as a restructuring of the management of budgetary resources at three different levels (Local, Government, Regional). In addition, they were asked to capture the fiscal policy mix that they perceive on the basis of their personal information. The recording was performed on a percentage scale as a percentage at two or three levels. Figures 5, 6, 7 and 8 below show the percentages of taxpayers who want to manage tax revenue initially in two (government and local) or three levels (government, regional/European and local).

In addition, the taxpayer was asked to answer what level of tax revenue management they trust most among three levels (government, European and local). The assessment of the solvency of tax revenues at three levels is recorded as follows:

From the governance table of the management of state resources, there appears to be a preference for management at the central level and at least at the local or even regional level. Between central and local, central is clearly preferred, while in a central, local and regional structure, it is preferred that the main structure be centralized, with less local and even less regional.

Between central and European, there is a clear preference for government revenue to be managed at a central level rather than at the European level since roughly two out of three respondents prefer centralized European tax revenue management. However, in terms of the credibility of government revenue management, taxpayers appear to have more confidence in European management and fewer taxpayers have nearly equal confidence in both central and local government. Mixed government revenue management at the central, European and local levels is acceptable. 
Table 1 Individual characteristics of participants

\begin{tabular}{|c|c|c|c|c|c|}
\hline Characteristics & Dimensions & & Participants & Percentages \% & $\begin{array}{l}\text { Cumulative } \\
\text { percentages }\end{array}$ \\
\hline \multirow[t]{4}{*}{ Age } & Ages & $18-35$ & 120 & 37.5 & 37.5 \\
\hline & & $36-50$ & 147 & 45.0 & 83.40 \\
\hline & & $51-65$ & 52 & 16.3 & 99.70 \\
\hline & & 65-above & 1 & 0.3 & 100.00 \\
\hline \multirow[t]{4}{*}{ Family condition } & Marital status & Single & 148 & 46.3 & 46.3 \\
\hline & & Married & 139 & 43.4 & 89.7 \\
\hline & & Widowed & 6 & 1.9 & 91.6 \\
\hline & & Divorced & 27 & 8.4 & 100.00 \\
\hline \multirow{4}{*}{$\begin{array}{l}\text { Permanent accom- } \\
\text { modation }\end{array}$} & Place & Attiki & 152 & 47.5 & 47.5 \\
\hline & & N. Greece & 108 & 33.8 & 81.3 \\
\hline & & Islands & 21 & 6.6 & 87.8 \\
\hline & & Rest & 39 & 12.2 & 100.00 \\
\hline \multirow[t]{4}{*}{ Profession } & Rating & Employed & 198 & 61.9 & 61.9 \\
\hline & & Retired & 20 & 6.3 & 68.1 \\
\hline & & Rentier & 17 & 5.3 & 73.4 \\
\hline & & Practician & 85 & 26.6 & 100.00 \\
\hline \multirow{4}{*}{$\begin{array}{l}\text { Years of employ- } \\
\text { ment }\end{array}$} & Years & $0-5$ & 75 & 23.4 & 23.4 \\
\hline & & $6-15$ & 105 & 32.8 & 56.3 \\
\hline & & $16-30$ & 116 & 36.3 & 92.5 \\
\hline & & 31-above & 24 & 7.5 & 100.00 \\
\hline \multirow[t]{4}{*}{ Education } & Level & High school & 78 & 24.4 & 24.4 \\
\hline & & Technical school & 137 & 11.6 & 35.9 \\
\hline & & University & 141 & 44.1 & 80.0 \\
\hline & & Postgraduate & 64 & 20.0 & 100.00 \\
\hline \multirow[t]{4}{*}{ Employment } & Sector & Private & 183 & 57.2 & 57.2 \\
\hline & & Public & 63 & 19.7 & 76.9 \\
\hline & & Unemployment & 43 & 13.4 & 90.3 \\
\hline & & Other & 31 & 9.7 & 100.00 \\
\hline \multirow[t]{4}{*}{ Declared income } & Stack (T. €) & $0-5$ & 85 & 26.6 & 26.6 \\
\hline & & $6-20$ & 154 & 48.1 & 74.7 \\
\hline & & $21-50$ & 70 & 21.9 & 96.6 \\
\hline & & 51-above & 11 & 3.4 & 100.00 \\
\hline Totals & & tal & 320 & 100.00 & \\
\hline
\end{tabular}

In contrast, taxpayers prefer a mixed level, where the management is more national than European, while they trust more European management than any other level. There is a sense of fear of having more confidence in European budget management, even though they consider it more credible and trustworthy. Additionally, interestingly enough, the structure of the costs that taxpayers prefer is as shown in Fig. 9.

From Fig. 9, it appears that in a restructuring of budgetary expenditure, it is preferable to focus on spending on Health, Education, Social Security and Public Investment. In relation to existing state budget expenditures, there is a feeling that much more than taxpayers would like is spent on servicing public debt. Nevertheless, this is not confirmed by the apparently fewer actual amounts of the state budget being directed towards the public debt. Characteristically, taxpayers have been reconciled with the 

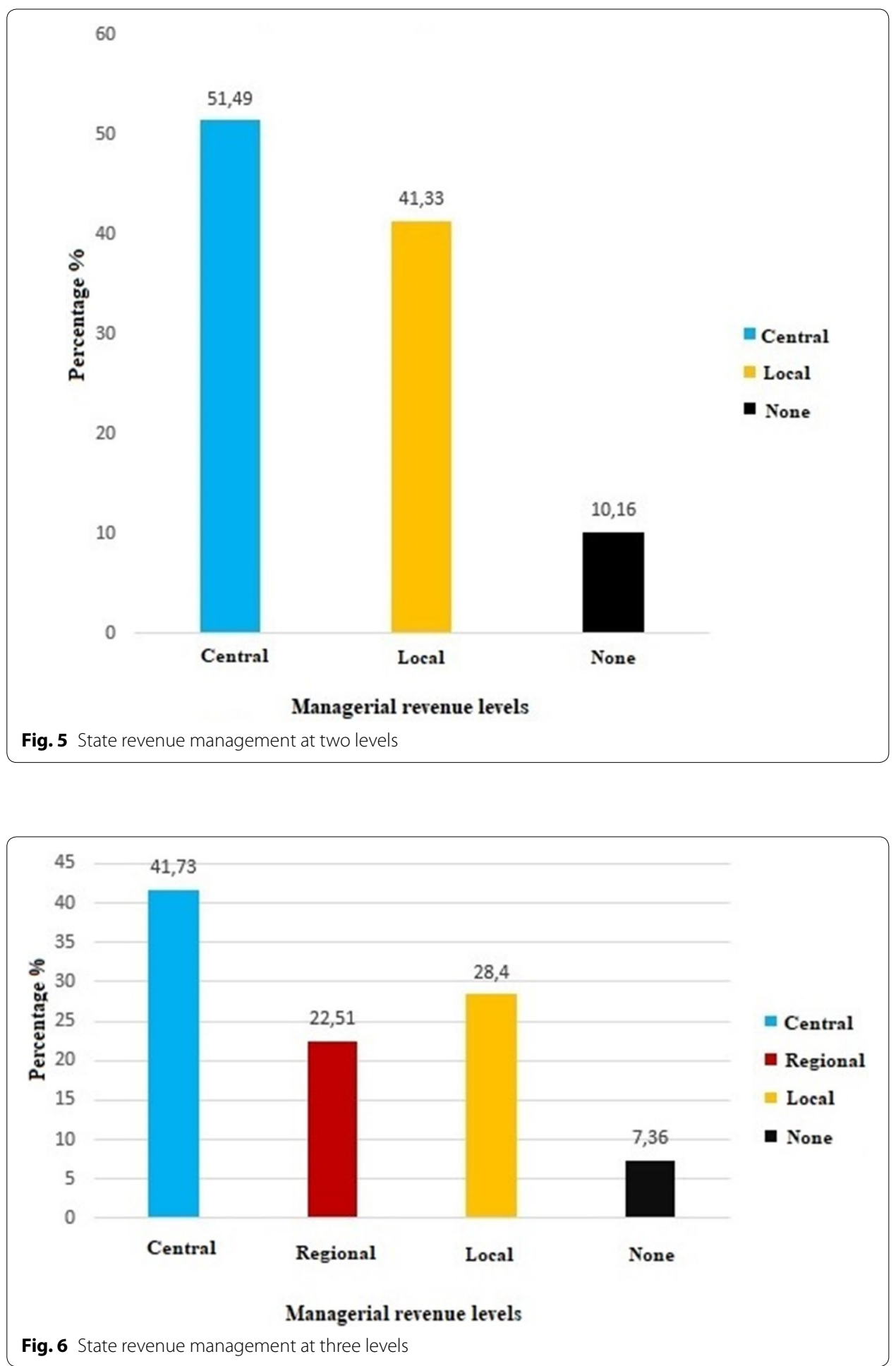

existence of illegality, expecting it to be even less than what is actually recorded, while in 2017 it rose into 21.5\% (Medina and Schneider 2018). 

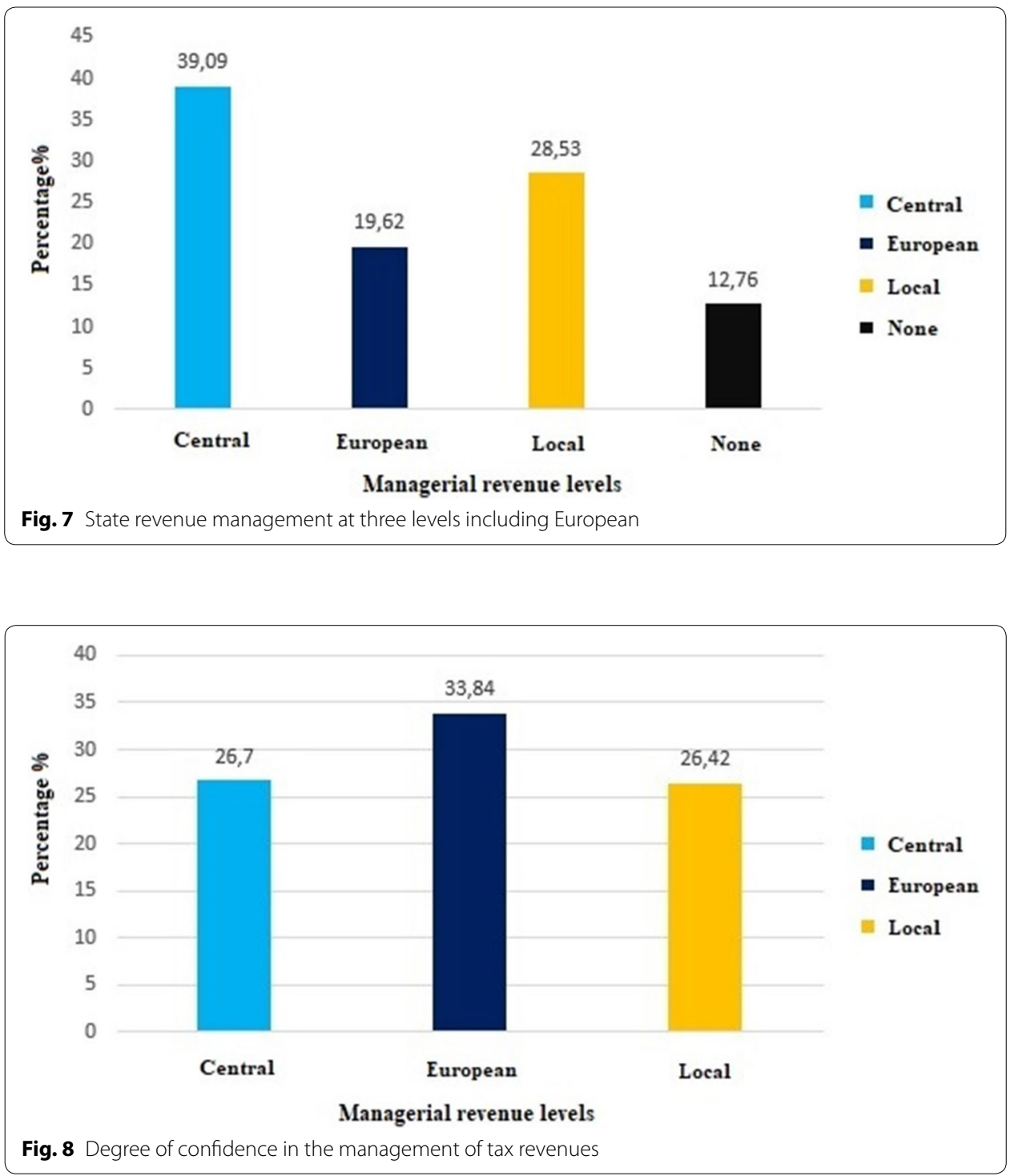

\section{Discussion}

Applying a tax model that reproduces increases in tax rates and overdue debts leads to periodic financial cessation (Velasco 1987). Unpredictable fiscal balances and weak positive increases in economic growth simply confirm the failure to achieve a sound economic model that brings social prosperity, especially when 10 years of regular tax adaptation has been preceded by increasing taxation. The 8 years of continued economic contraction of the Greek economy, while fiscal policy has changed radically and tax evasion has remained at the same level, has simply confirmed not only the fragile economic structure, but also the failure of the financial mix. The gradual consolidation of the banking system has not been reflected in the real economy, raising questions about the importance attributed to this factor in the Greek economy. 


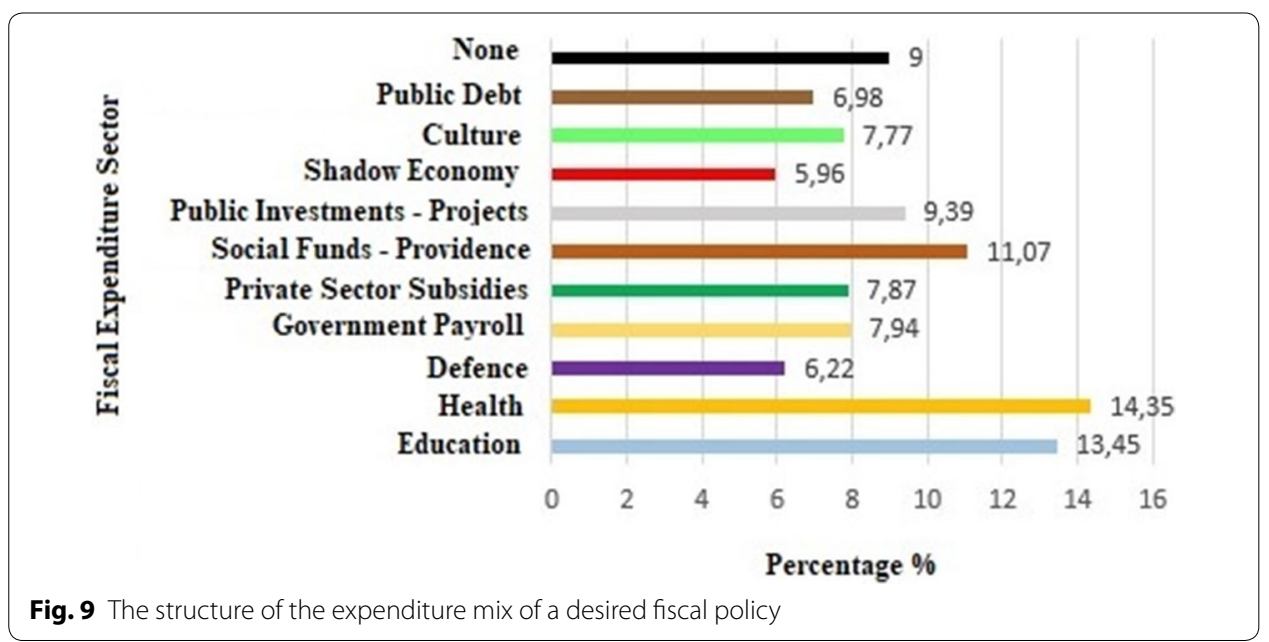

Restructuring the tax model (Varotsis et al. 2017) is imperative for the growth of the Greek economy. The implementation of cyber-centric management models and tax revenues, apart from the failure in fiscal management leading to the Greek economy's bankruptcy, maintain an unprecedented centralized management without positive results for the Greek economy. The dependence of local actors on government-cantered budget management over time makes it harder to improve their finances. Disengagement of local actors from the state budget can improve public finances by helping to manage transparency and fiscal reform.

The choice of the fiscal model that will allocate tax decentralization requires further study. Important elements that need to be thoroughly investigated are: the tax sector to be followed by fiscal decentralization (direct taxation, indirect taxation, real estate), the transparency of their management by local authorities, the degree of centralized management control, the autonomy of local policy budgets, and the legal compliance status of taxpayers' response. In any case, one of the key points of tax absorption is the extent to which tax revenue is consistent with the tax and the public autonomy of local authorities.

Institutionalization, as well as the legal defence of fiscal decentralization, is one of the major steps towards achieving reform. To achieve maximum compliance by the taxpayer, transparency and fairness can be legally ensured by local resource management bodies. A fiscal planning model that incorporates fiscal, socio-psychological and decentralizing data is likely to contribute to fiscal restructuring, thereby shrinking the shadow economy and contributing to tax compliance.

While both the tax system and the fiscal mix have changed many times over the last decade, the shadow economy remains strong, confirming not only the fragile economic background of the Greek economy and the failure of reform policies, but also that none of these changes had social acceptance among the tax base. This continuing phenomenon of the shadow economy in Greece concerns the extent to which all of these reforms were socially acceptable or simply avoided the problem of tax evasion by Greek citizens. The tax system does not appear to be acceptable, and the attitudes and emotions it evokes can be broadened and tested in more models of tax management. Tax behaviour is very likely to be 
interpreted by a non-linear model, and the social acceptance of a new model of tax revenue management is a necessary factor in its effectiveness.

\section{Conclusion}

The present survey shows that the tax base in Greece is accepting of a radical overhaul of public revenue management coupled with a mix of fiscal spending. Especially with regard to the mix of budgetary expenditure, there is a clear preference for a socio-economic expenditure management rather than an investment-centric management. A radical restructuring of the tax system is likely to be acceptable for the management of public revenue, which will be managed more locally/regionally than it is today. Mixed management of tax revenues at three levels, i.e., local/regional, government and European, seems to be acceptable.

\section{Abbreviations}

AADE: Independent Principle of Public Revenues in Greece; OECD: Organization for Economic Co-Operation and Development.

\section{Acknowledgements}

Not applicable.

\section{Authors' contributions}

The collection, processing and analysis of the data were carried out by the authors. Both authors read and approved the final manuscript.

\section{Funding}

The research was funded by the authors.

Availability of data and materials

The authors declare they can submit the data at any time based on the publisher's request. The datasets used and/or analysed during the current research are available from the authors upon reasonable request.

Competing interests

The authors declare that they have no competing interests.

\section{Author details}

${ }^{1}$ Tourism Department, Ionian University, Building "Calypso", P. Vraila Armeni 4, 49100 Corfu, Greece. ${ }^{2}$ Psychology Department, Panteion-University, 17671 Athens, Attica, Greece.

Received: 31 May 2019 Revised: 7 November 2019 Accepted: 18 January 2020

Published online: 03 February 2020

\section{References}

AADE (2019) At EUR 104.652 billion in February 2019, the outstanding debt to the public. Independent Public Revenue Authority (AADE), Athens

Allan JP, Scruggs L (2004) Political partisanship and welfare state reform in advanced industrial societies. Am J Pol Sci 48:496-512

Alogoskoufis G (2019) Greece and the Euro: a Mundellian tragedy. CGK working paper no. 1. Tufts University, Massachusetts

Anderson K (2001) The politics of retrenchment in a social democratic welfare state. Comp Polit Stud 34:1063-1091 Andreoni J, Erard B, Feinstein J (1998) Tax compliance. J Econ Lit 36:818-860

Barth E, Cappelen AW, Ogendal T (2013) Fair tax evasion. Nord J Pol Econ 38:1-16

Braithwaite J, Walker J, Grabosky P (1987) An enforcement taxonomy of regulatory agencies. Law Policy 9:323-351

Bruce D, Fox WF, Tuttle MH (2006) Tax base elasticities: a multi-state analysis of long-run and short-run dynamics. South Econ J 73:315-34

Bryman A (2012) Social research methods. Oxford University Press, Oxford, pp 653-681

Conlisk J (1996) Why bounded rationality? J Econ Lit 34:669-700

Council of Europe (2000) The financial resources of local authorities in relation to their responsibilities: a litmus test for subsidiary

Cullis JG, Lewis A (1997) Why people pay taxes: from a conventional economic model to a model of social convention. J Econ Psychol 18:305-321

Davulis G, Peleckis K, Slavinskaite N (2013) Development of local municipality taxes and principles of fiscal policy in Lithuania. Am Int J Contemp Res 3:38-50

Easterly W, Rebelo S (1993) Fiscal policy and economic growth: an empirical investigation. J Monetary Econ 32:417-458

Edwards W (1954) The theory of decision making. Psychol Bull 51:380-417 
European Commission (2017) European Economy. Report in public finance in EMU. https://urldefense.proofpoint.com/ v2/url?u=https-3A_ec.europa.eu_info_publications_economy-2Dfinance_report-2Dpublic-2Dfinances-2Demu -2D2017-5Fen\&d=DwIDaQ\&c=vh6FgFnduejNhPPD0fl_yRaSfZy8CWbWnlf4XJhSqx8\&r=_tDouL3h-1LDiBK93Wj 27DvOJuSTpUjtL_R9oBJNIXM\&m=X50687Hkgs59W1SObEjdWAsS-2dKZaCNNKXUCw_WDE\&s=bJsIUliajbBkOrh 6DIHIb833eVfXWqITRBjQdLwo92s\&e=. Accessed 06 Nov 2019

Fehr E, Schmidt KM (1999) A theory of fairness, competition, and cooperation. Q J Econ 114:817-868

Gainous J, Martinez MD, Craig SC (2010) The multiple causes of citizen ambivalence: attitudes about social welfare policy. J Elect Public Opin Parties 20:335-356

Greek Tax Code (2008) Prevent and suppress money laundering, criminal activities and the financing of terrorism. Law, 3691/2008. A 166/08. The National Printing House (Ethniko Typografeio), Athens. pp 3129-3160

Greek Tax Code (2013a) Tax income. Law, 4172/2013. A 167/13. The National Printing House (Ethniko Typografeio), Athens. pp 2457-2516

Greek Tax Code (2013b) Tax procedures. Law, 4174/2013. A 170/13. The National Printing House (Ethniko Typografeio), Athens. pp 2533-2556

Greek Tax Code (2014) Greek accounting standards. Law, 4308/2014. A 251/14. The National Printing House (Ethniko Typografeio), Athens. pp 7651-7746

Heymans C (2006) Local government organization and finance: South Africa. In: Shah A (ed) Local governance in developing countries. The World Bank, Washington, DC, pp 47-92

Iversen T (1996) Power, flexibility, and the breakdown of centralized wage bargaining: Denmark and Sweden in comparative perspective. Comp Polit 28:399-436

Kaplow L (1996) How tax complexity and enforcement affect the equity and efficiency of the income tax. Natl Tax J 49:135-150

Katerelos I, Varotsis N (2017) A cusp catastrophe model of tax behavior. Nonlinear Dyn Psychol Life Sci 21:89-112

Katsimi M, Moutos T (2010) EMU and the Greek crisis: the political-economy perspective. Eur J Pol Econ 26:568-576

Keltner D, Kring A (1998) Emotion, social function, and psychopathology. Rev Gen Psychol 2:320-342

Kirchler E, Hoelzl E, Wahl I (2008) Enforced versus voluntary tax compliance: the "slippery slope" framework. J Econ Psychol 29:210-225

Laffer AB (2004) The Laffer curve: past, present and future. The Heritage Foundation, Washington, DC

Lane WC (1976) Consensus, conflict, and international stratification theories of modernization: an evaluation. Mid-American Rev Sociol 1:19-32

Matei L, LazĂR C-G (2011) Quality management and the reform of public administration in several states in South-Eastern Europe. Comparative analysis. Theor Appl Econ. XVIII:65-98

McMillan J, Woodruff C (2002) The central role of entrepreneurs in transition economies. In: Fields GS, Pfeffermann G (eds) Pathways out of poverty: private firms and economic mobility in developing countries. Springer, Netherlands, Dordrecht, pp 105-121

Méder ZZ, Simonovits A, Vincze J (2012) Tax morale and tax evasion: social preferences and bounded rationality. Econ Anal Policy 42:171-188

Medina L, Schneider F (2018) Shadow economies around the world: what did we learn over the last 20 years? International Monetary Fund. WP/18/17, Washington

Murphy K (2008) Enforcing tax compliance: to punish or persuade? Econ Anal Policy 38:113-135

Naftemporiki (2017) Tax instability with 106 laws. https://www.naftemporiki.gr/finance/story/1294750/forologiki-astat heia-me-106-nomous. Accessed 10 May 2019

Nantell SC (1999) A cultural perspective on American tax policy. Chapman Law Rev 2:33-93

OECD (2010) Citizen-state relations: improving governance through tax reform. TPA, OECD, Paris

O'Neill B, Sorhaindo B, Xiao JJ, Garman E (2005) Financially distressed consumers: their financial practices, financial wellbeing, and health. Financ Couns Plan 16:73-87

Peredo AM, McLean M (2006) Social entrepreneurship: a critical review of the concept. J World Bus 41:56-65

Perez SA, Westrup J (2010) Finance and the macroeconomy: the politics of regulatory reform in Europe. J Eur Public Policy 17:1171-1192

Porter ME (1996) Competitive advantage, agglomeration economies, and regional policy. Int Reg Sci Rev 19:85-90 Reips U-D (2002) Standards for internet-based experimenting. Exp Psychol 49:243-256

Robbins B, Kiser E (2018) Legitimate authorities and rational taxpayers: an investigation of voluntary compliance and method effects in a survey experiment of income tax evasion. Ration Soc 30:247-301

Ross L, Greene D, House P (1977) The "false consensus effect": an egocentric bias in social perception and attribution processes. J Exp Soc Psychol 13:279-301

Slemrod J (2001) A general model of the behavioral response to taxation. Int Tax Public Financ 8:119-128

Slemrod J (2007) Cheating ourselves: the economics of tax evasion. J Econ Perspect 21:25-48

Sutinen JG, Kuperan K (1999) A socio-economic theory of regulatory compliance. J Soc Econ 26:174-193

Tøssebro J, Bonfils IS, Teittinen A, Tideman M, Traustadóttir R, Vesala HT (2012) Normalization fifty years beyond_current trends in the Nordic countries. J Policy Pract Intellect Disabil 9:134-146

Tversky A, Kahneman D (1974) Judgment under uncertainty: heuristics and biases. Science 185:1124 van Dijke M, Verboon P (2010) Trust in authorities as a boundary condition to procedural fairness effects on tax compliance. J Econ Psychol 31:80-91

Varotsis N, Katerelos I (2018) Models of tax planning simulation: the case of Greece. OJMSI 6:27-44

Varotsis N, Katerelos I, Ladias CA (2017) Systemdynamik einer steuerreform: Der FallL Griechenland. Z Reg Wiss VIII:29-44

Velasco A (1987) Financial crises and balance of payments crises: a simple model of the southern cone experience. J Dev Econ 27:263-283

Weingast B (1995) The economic role of political institutions: market-preserving federalism and economic development. J Law Econ Organ 11:1-31

Weller SC (2007) Cultural consensus theory: applications and frequently asked questions. Field Methods 19:339-368

Wenzel M (2004) An analysis of norm processes in tax compliance. J Econ Psychol 25:213-228 
Wood JV (1989) Theory and research concerning social comparisons of personal attributes. Psychol Bull 106:231-248 Young HP (1990) Progressive taxation and equal sacrifice. Am Econ Rev 80:253-266

\section{Publisher's Note}

Springer Nature remains neutral with regard to jurisdictional claims in published maps and institutional affiliations.

Submit your manuscript to a SpringerOpen ${ }^{\circ}$ journal and benefit from:

- Convenient online submission

- Rigorous peer review

- Open access: articles freely available online

- High visibility within the field

- Retaining the copyright to your article

Submit your next manuscript at $\gg$ springeropen.com 